\title{
Comparison of the adsorption capacity of acetaminophen on sugarcane bagasse and corn cob by dynamic simulation
}

\author{
Diego M. Juela(1)
}

\begin{abstract}
Acetaminophen (ACT), an antipyretic analgesic, is one of the emerging pollutants that has been found in high concentrations in domestic and hospital wastewaters. This study compared the adsorption capacity of sugarcane bagasse (SB) and corn cob (CC) for the ACT removal through the dynamic simulation of the adsorption column using Aspen Adsorption ${ }^{\circledR}$ V10. The effects of flow rate (1.5-3.0 $\left.\mathrm{mL} \mathrm{min}^{-1}\right)$, ACT initial concentration $\left(40-80 \mathrm{mg} \mathrm{L}^{-1}\right)$, and bed height $(20-35 \mathrm{~cm})$ on the breakthrough curves were studied. Finally, the simulation results were validated with experimental studies, and analyzed by error functions, sum of squared errors (SSE), absolute average deviation (AAD), and coefficient of determination $\left(R^{2}\right)$. Based on the predicted breakthrough curves, $A C T$ is adsorbed in greater quantity on CC, with saturation times and adsorption capacity greater than SB in all simulations. The maximum adsorption capacity was 0.47 and $0.32 \mathrm{mg} \mathrm{g}^{-1}$ for $C C$ and $\mathrm{SB}$, respectively, under condition of flow rate of $1.5 \mathrm{~mL} \mathrm{~min}{ }^{-1}$, bed height of $25 \mathrm{~cm}$, and ACT initial concentration of $80 \mathrm{mg} \mathrm{L}^{-1}$. Breakthrough and saturation times were higher when the column operated at low flow rates, large bed height, and low ACT concentrations, for both adsorbents. The predicted and experimental breakthrough curves satisfactorily coincided with $R^{2}$ values greater than 0.97, SSE and AAD values less than $5 \%$ and 0.2 , respectively, for all studies. The experimental adsorption capacity was greater for CC than for SB, thus confirming that the software is able to predict which adsorbent may be more effective for ACT removal. The results of this study would speed up the search for effective materials to remove ACT from wastewaters.
\end{abstract}

Keywords: Dynamic simulation, Aspen adsorption ${ }^{\oplus}$, Sugarcane bagasse, Corn cob, Acetaminophen, Adsorption capacity

\section{Introduction}

Pharmaceutical products are one of the emerging pollutants that have been of particular concern. In recent years, their presence has been detected in domestic and hospital wastewaters [1]. Pharmaceutical products are chemical compounds of complex structures of synthetic or natural origin, they contain active ingredients intended to counteract negative effects on the health of human and animals. These drugs end up in wastewater due to improper disposal of expired or unused drugs,

Correspondence: diego.juela@ucuenca.edu.ec

Department of Chemical Engineering, University of Cuenca, 010107 Cuenca, Ecuador

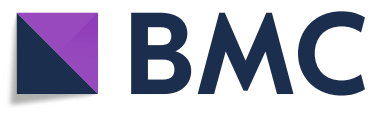

through urine and feces of patients and animals, leachate from soils, as well as domestic and hospital waste [2]. When these compounds reach the wastewater treatment plants (WTPs), there is no effective technology that can completely eliminate this type of pollutants, so their removal is only partial [3]. As a result of this, traces of these pollutants have been found in surface water, groundwater, and even in drinking water from various countries in concentrations of ng $\mathrm{L}^{-1}, \mu \mathrm{g} \mathrm{L}^{-1}$ and up to $\mathrm{mg} \mathrm{L} \mathrm{L}^{-1}[4,5]$.

In particular, acetaminophen (ACT), better known as paracetamol, is one of the most prescribed antiinflammatory and antipyretic drugs, and consequently,

(c) The Author(s). 2020 Open Access This article is licensed under a Creative Commons Attribution 4.0 International License, which permits use, sharing, adaptation, distribution and reproduction in any medium or format, as long as you give appropriate credit to the original author(s) and the source, provide a link to the Creative Commons licence, and indicate if changes were made. The images or other third party material in this article are included in the article's Creative Commons licence, unless indicated otherwise in a credit line to the material. If material is not included in the article's Creative Commons licence and your intended use is not permitted by statutory regulation or exceeds the permitted use, you will need to obtain permission directly from the copyright holder. To view a copy of this licence, visit http://creativecommons.org/licenses/by/4.0/. 
the most widely used in Latin America, Africa and the Middle East [6]. In countries such as Spain, USA, France and UK, ACT has been detected in the effluents of WTPs in a concentration range of $0.10-150 \mu \mathrm{g} \mathrm{L}^{-1}[7$, 8]. In surface water, ACT has reached maximum concentrations of up to $15 \mu \mathrm{g} \mathrm{L}^{-1}$, in Taiwan and Kenya [9, 10]. Likewise, in groundwater and drinking water of USA, ACT has been found in concentrations of 0.12 , and $1.89 \mu \mathrm{g} \mathrm{L}^{-1}$, respectively [11]. Although the concentrations detected in most countries are at a very low level $\left(\mu \mathrm{g} \mathrm{L}^{-1}\right)$, recent researches have exposed negative effects of some aquatic organisms exposed to these levels, such as DNA and reproductive system damage, oxidative stress, tissue accumulation, lipid peroxidation, and behavioral changes observed in algae, microcrustaceans, mollusks, and teleost fish [12].

All these adverse effects can be avoided if the domestic and hospital wastewaters were properly treated. To achieve this, it is necessary to research novel, efficient, eco-friendly, and above all, economically viable technologies for their implementation in WTPs. Adsorption using agricultural and agro-industrial residues as adsorbents, is presented as an efficient, low-cost, and environmentally sustainable alternative, compared to other available technologies such as membrane filtration, advanced oxidation, photocatalysis, and others [13]. In addition, adsorption has certain advantages such as ease in design, implementation and operation, efficient with pollutants at low concentrations, and it does not generate toxic by-products. There are a large number of agricultural and agro-industrial materials that can be used as adsorbents, among these are, grape stalks, rice husk, tea leaves, pineapple leaves, sugarcane bagasse (SB), peanut shell, corn cob $(\mathrm{CC})$, coconut shell and fiber, bamboo litter, ground coffee and banana stalks [14-16]. SB and CC are two potential adsorbents for the treatment of wastewaters laden with any type of pollutant. In their natural state, they have been widely used for the removal of dyes, heavy metals and pharmaceutical products [17-19].

In a continuous adsorption system, the adsorption capacity of an adsorbent depends on the operating conditions of the column like bed height, flow rate, pollutant concentration in the feed, and $\mathrm{pH}$ of the solution. The physicochemical properties of the system adsorbate-adsorbent also influence the adsorption capacity, such as the porosity and the specific surface area of the adsorbent, as well as the chemical properties like the point of zero charge, the dissociation constant $\mathrm{pK}_{\mathrm{a}}$, and the functional groups of the adsorbate and adsorbent. Even if all these properties were known, in most cases it is difficult to theoretically predict which adsorbent is more effective for a specific adsorbate, therefore it is essential to carry out experimentation, and obviously that adsorption tests consume an undesirable expenditure of resources and time.
One way to predict the dynamic behavior of an adsorption column is through the approach of mathematical models; these models generally consist of a set of equations from the conservation of mass, kinetic models, and equilibrium adsorption. A mathematical model that includes these equations is capable of estimating the adsorbate concentration at the outlet of the column, as well as the concentration of the adsorbate in the adsorbed phase. Aspen Adsorption is a software that includes mathematical models with a complete set of fairly complex partial differential equations, ordinary differential equations, and algebraic equations [20]. These equations together with the appropriate initial and boundary conditions, are solved simultaneously through numerical methods, to fully describe the dynamic behavior of an adsorption column. Aspen Adsorption ${ }^{\circ}$ has typically been used to simulate gas phase adsorption processes, such as $\mathrm{CO}_{2}$ and $\mathrm{CO}$ adsorption, $\mathrm{H}_{2}$ and $\mathrm{He}$ purification $[21,22]$. As for the aqueous systems, the adsorption of $\mathrm{Cd}^{+2}, \mathrm{Cu}^{+2}$, phenol and melanoidin has been simulated [23, 24], however, as of yet there are no previous studies of the simulation of pharmaceutical products using Aspen Adsorption.

In this study, the adsorption capacity of SB and CC for the ACT removal was compared through predicted breakthrough curves by a model proposed in Aspen Adsorption $^{\circ}$ V10. The model studied breakthrough curves in both adsorbents, at different operating conditions of the adsorption column (feed flow, bed height and ACT concentration). The simulation results were validated with experimental studies.

\section{Materials and methods}

\section{Experimental information}

The simulation of the ACT adsorption in fixed bed columns using SB and CC was performed using Aspen Adsorption $^{\circ} \mathrm{V} 10$. The physical properties of the adsorbents were obtained from the study by Vera et al. [19] as shown in Table 1. Also, Fig. 1 shows the morphological structure of SB and CC obtained by scanning electron microscopy.

\section{Simulation in Aspen adsorption ${ }^{\circledR}$ V10 General considerations}

Liquid phase adsorption was chosen as the process for the ACT removal. The assumptions for bed model of the ACT adsorption were:

1) Plug flow with axial dispersion was considered in the behavior of the fluid.

2) There is a concentration gradient of ACT only in the longitudinal direction of the bed, and it is neglected in the radial direction.

3) The rate of adsorption of ACT on the adsorbents is described by the linear driving force model (LDF). 
Table 1 Physicochemical properties of adsorbents [19, 25]

\begin{tabular}{lll}
\hline Property & Adsorbent & \\
\cline { 2 - 3 } & CC & SB \\
\hline Bed bulk density $\left(\mathrm{kg} \mathrm{m}^{-3}\right)$ & 334 & 150 \\
Particle density $\left(\mathrm{kg} \mathrm{m}^{-3}\right)$ & 816 & 1078 \\
Bed void fraction & 0.71 & 0.86 \\
Average particle diameter $(\mathrm{m})$ & $5.9 \times 10^{-4}$ & $5.9 \times 10^{-4}$ \\
Average pore radius $(\mathrm{m})$ & $5.48 \times 10^{-9}$ & $3.26 \times 10^{-8}$ \\
Particle porosity & 0.59 & 0.21 \\
Specific surface area $\left(\mathrm{m}^{2} \mathrm{~g}^{-1}\right)$ & $5.3 \pm 0.8$ & $4.8 \pm 0.7$ \\
Specific pore volume $\left(\mathrm{cm}^{3} \mathrm{~g}^{-1}\right)$ & 0.006 & 0.005 \\
Tortuosity factor & 1.21 & 1.40 \\
Point of zero charge $\mathrm{pH}_{P Z C}$ & 6.3 & 5.2 \\
Total acid groups $\left(\mathrm{meq} \mathrm{g}^{-1}\right)$ & 2.25 & 2.33 \\
Total basic groups $\left(\mathrm{meq} \mathrm{g}^{-1}\right)$ & 0.25 & 0.55 \\
\hline
\end{tabular}

4) The adsorption equilibrium is described by the Langmuir nonlinear isotherm, according to studies by other $[25,26]$.

5) Due to the existence of large pores in the adsorbents, surface diffusion was neglected and pore diffusion was assumed (see Table 1).

6) The pore diameter of the adsorbents is considered to be slightly larger than the diameter of the ACT molecule $(\sim 0.46 \mathrm{~nm})$ [27], therefore Knudsen diffusion was taken into account.

7) The particle bed has a constant cross section throughout the bed.

8) The adsorption system operates under isothermal conditions.

9) The linear velocity of the fluid phase varies along the column, but is neglected in the radial direction.

10) The particles of the adsorbents are considered spherical with homogeneous in size and density.

\section{Physical and chemical properties of ACT}

Aspen Properties ${ }^{\circ}$ V10 provided the physical and chemical properties of the ACT solution. The Non-Random Two Liquid Segment Activity Coefficients (NRTL-SAC) model was used to estimate the thermodynamic properties of the solution [28]. The molecular structure and the physicochemical properties of ACT can be found in the Supporting Information Fig. S1.

\section{Simulation parameters}

The process flowsheet of the adsorption process consists of 3 blocks: feed block, adsorption column block, and product block (see Supporting Information Fig. S2). Within the feed block, ACT initial concentration $C_{i}(\mathrm{mg}$ $\left.\mathrm{L}^{-1}\right)$, temperature $T\left({ }^{\circ} \mathrm{C}\right)$, flow rate $Q\left(\mathrm{~mL} \mathrm{~min}^{-1}\right)$, and pressure $P_{i}(\mathrm{~Pa})$ of the feed stream were controlled. $T$ $\left(18^{\circ} \mathrm{C}\right)$ and $P_{i} \quad(0.1 \mathrm{MPa})$ were fixed specifications throughout the study, whereas, $Q$ and $C_{i}$ were variable specifications, and are detailed in Table 2 .

Within the adsorption column block, the bed orientation was assumed as vertical with downward flow. The model was defined as a set of equations for the adsorbent bed layer, the equations are based on the momentum balance, mass balance, kinetic model, and adsorption isotherm.

\section{Momentum balance}

The pressure drop across the adsorption bed was expressed through the Carman-Kozeny equation, which is valid for laminar flows in porous media as shown in Eq. (1).

$$
\frac{\partial P}{\partial z} \frac{2 R_{p} \psi \varepsilon_{p}^{3}}{v_{s}\left(1-\varepsilon_{p}\right)}=\frac{-1.5 \times 10^{-3} \mu\left(1-\varepsilon_{p}\right)}{2 R_{p} \psi}
$$

Where, $P$ is the pressure across the bed $(\mathrm{Pa}), \psi$ is the form factor of the adsorbent particle, $\mu$ is the dynamic viscosity of the solution $\left(\mathrm{kg} \mathrm{m}^{-1} \mathrm{~s}^{-1}\right), \varepsilon_{p}$ is the particle
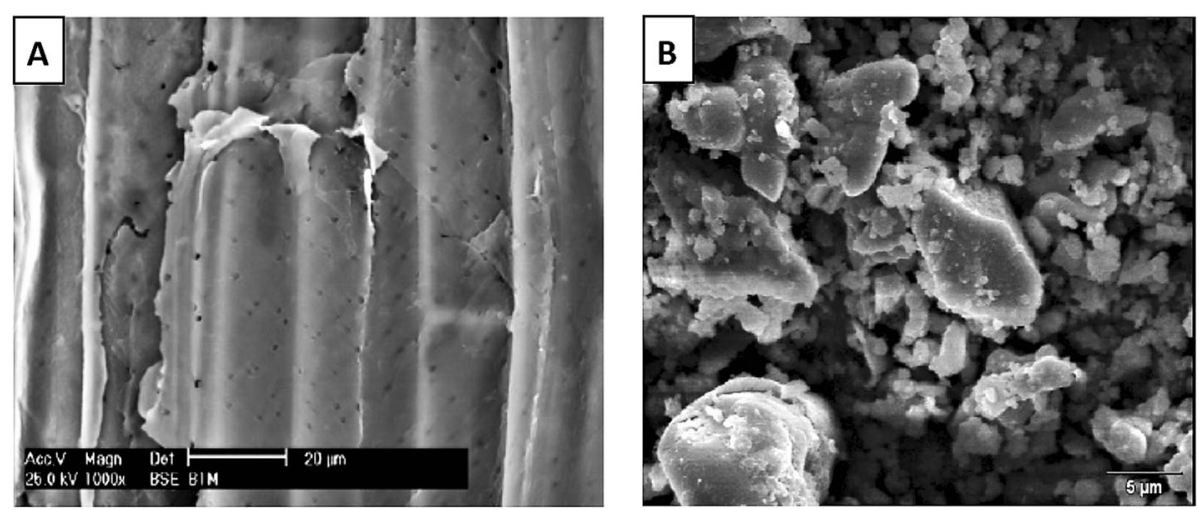

Fig. 1 Morphological structure of SB (a) and CC (b), adapted from Ref. [19] 
Table 2 Column operation parameters in ACT removal using SB and $\mathrm{CC}$

\begin{tabular}{|c|c|c|c|c|c|c|c|c|c|}
\hline \multicolumn{5}{|c|}{ Simulation } & \multicolumn{5}{|c|}{ Experimental } \\
\hline$\overline{Q^{a}}$ & $\mathrm{H}_{\mathrm{b}}^{\mathbf{b}}$ & $\mathrm{m}^{\mathrm{c}}$ & & $C_{i}^{d}$ & $\mathrm{Q}^{\mathbf{a}}$ & $\mathrm{H}_{\mathrm{b}}{ }^{\mathbf{b}}$ & $\mathrm{m}^{\mathbf{c}}$ & & $C_{i}^{d}$ \\
\hline & & SB & $\mathrm{CC}$ & & & & SB & $\mathrm{CC}$ & \\
\hline 1.5 & 20 & 5.31 & 11.79 & 20 & 1.5 & 20 & 6.60 & - & 60.08 \\
\hline 2 & 25 & 6.63 & 14.74 & 40 & 1.5 & 20 & - & 14.70 & 60.11 \\
\hline 2.5 & 30 & 7.96 & 17.69 & 60 & 2.65 & 23 & 6.10 & - & 50.27 \\
\hline 3 & 35 & 9.29 & 20.63 & 80 & 2.65 & 23 & - & 13.50 & 50.24 \\
\hline
\end{tabular}

porosity, $R_{p}$ is the particle radius (m), and $v_{s}$ is the superficial velocity of fluid through the bed $\left(\mathrm{m} \mathrm{s}^{-1}\right)$.

\section{Mass balance}

The partial mass balance in a volume element of the column for the ACT concentration is expressed by the following partial differential Eq. (2) [29].

$$
-\varepsilon_{b} D_{z} \frac{\partial^{2} C}{\partial z^{2}}+\frac{\partial\left(v_{i} C\right)}{\partial z}+\varepsilon_{b} \frac{\partial C}{\partial t}+\rho_{a} \frac{\partial q}{\partial t}=0
$$

Eq. (2) includes the phenomena of axial dispersion (1st term), mass transfer by convection (2nd term), accumulation of ACT in adsorbents (3rd term), and the last term caused by the process of adsorption of ACT on adsorbent particles. Where, $D_{Z}$ is the axial dispersion coefficient $\left(\mathrm{m}^{2} \mathrm{~s}^{-1}\right), q$ is the concentration of ACT adsorbed in the solid phase $\left(\mathrm{mgg}^{-1}\right), C$ is ACT concentration in the liquid phase $\left(\mathrm{mg} \mathrm{L}^{-1}\right), z$ is the distance along the bed $(\mathrm{m}), v_{i}$ is the interstitial velocity of fluid through the bed $\left(\mathrm{m} \mathrm{s}^{-1}\right), \varepsilon_{b}$ is the bed void fraction, and $\rho_{a}$ is the bed bulk density $\left(\mathrm{kg} \mathrm{m}^{-3}\right) . D_{z}$ was estimated with Eq. (3) [23].

$$
\frac{v_{i} d_{p}}{D_{z}}=0.2+0.011\left(\frac{R e}{\varepsilon_{b}}\right)^{0.48}
$$

Where, $d_{p}$ is the diameter of the adsorbent particle $(\mathrm{m})$, and $R e$ is the Reynolds number. The corresponding values of $D_{Z}$ used in this study can be found in the Supporting Information.

\section{Kinetic model}

The assumed kinetic model was linear lumped resistance, it was proposed by Glueckauf and Coates [30], and it is based on the LDF model in solid phase where the mass transfer phenomena are grouped as a single global factor, Eq. (4).

$$
\frac{\partial q}{\partial t}=K_{i}\left(q_{e}-q\right)
$$

Where, $q_{e}$ is the instantaneous equilibrium concentration $\left(\mathrm{mg} \mathrm{g}^{-1}\right)$ and $K_{i}$ is the global mass transfer coefficient $\left(\mathrm{s}^{-1}\right)$. When the external fluid film resistance, and pore diffusional resistance are considered, $K_{i}$ can be estimated by Eq. (5) [31].

$$
\frac{1}{K_{i}}=\frac{R_{P}}{3 k_{f i}}+\frac{R_{p}^{2}}{15 \varepsilon_{p} D_{p}}
$$

Where, $k_{f i}$ is the external film mass transfer coefficient of adsorbate $\mathrm{i}\left(\mathrm{m} \mathrm{s}^{-1}\right)$ and $D_{p}$ is the effective pore diffusivity coefficient $\left(\mathrm{m}^{2} \mathrm{~s}^{-1}\right)$. The missing parameters: $k_{f i}, D_{p}$, Knudsen diffusion coefficient $D_{k}\left(\mathrm{~m}^{2} \mathrm{~s}^{-1}\right)$, and ACT molecular diffusion coefficient $D_{m}\left(\mathrm{~m}^{2} \mathrm{~s}^{-1}\right)$, were estimated by empirical correlations (See Supporting Information for details Table S1, Table S3 and Table S4).

\section{Adsorption isotherm}

The equilibrium model for the adsorption of ACT on SB and $\mathrm{CC}$ used in this study was described by the Langmuir isotherm [25, 26]. Langmuir's model is expressed in Eq. (6).

$$
q_{e}=\frac{q_{\max } \cdot k_{L} \cdot C}{1+k_{L} \cdot C} \quad w_{i}=\frac{I P_{1} \cdot I P_{2} \cdot C}{1+I P_{2} \cdot C}
$$

The equation on the left side is the common form of the Langmuir isotherm, while on the right side it is the form that Aspen Adsorption ${ }^{\circ}$ presents this isotherm. Where, $q_{e}$ and $w_{i}$ are the amount of solute removed per unit mass of adsorbent ( $\mathrm{mg} \mathrm{g}^{-1}$ and $\mathrm{kmol} \mathrm{kg}^{-1}$, respectively), $q_{\max }$ and $I P_{1}$ are the maximum adsorption of the solid phase in monolayer $\left(\mathrm{mg} \mathrm{g}^{-1}\right.$ and $\mathrm{kmol} \mathrm{kg}^{-1}$ respectively), $k_{L}$ and $I P_{2}$ are the energy constant related to the heat of adsorption ( $\mathrm{L} \mathrm{mg}^{-1}$ and $\mathrm{m}^{3} \mathrm{kmol}^{-1}$, respectively). The values of $I P_{1}$ and $I P_{2}$ can be obtained from Eq. (7), where $M$ is the molecular weight of ACT $\left(\mathrm{g} \mathrm{moL}^{-1}\right)$. The $k_{L}$ and $q_{\max }$ parameters are 0.051 and 0.253 for ACT-SB, and 0.048 and 0.314 for ACT-CC, respectively $[25,26]$.

$$
I P_{1}=\frac{q_{\max }}{1000 \mathrm{M}} ; \quad I P_{2}=1000 k_{L} M
$$

In the adsorption column block, the bed height $H_{b}$ $(\mathrm{cm})$ was a variable specification (Table 2). Furthermore, in the product block, the flow rate and temperature in this stream were kept at the same values as the feed stream, while the pressure was estimated with Eq. (1). Finally, the discretization method Upwind Differencing Scheme 1 with 20 nodes was assumed as the method for solving the set of equations of the model.

\section{Study of column performance}

Column performance for SB and CC was studied by estimating the breakthrough time $t_{\text {break }}(\mathrm{min})$, the saturation 
time $t_{\text {sat }}(\mathrm{min})$, the total treated volume $V_{\text {eff }}(\mathrm{mL})$, the total amount of ACT adsorbed $q_{\text {total }}(\mathrm{mg})$, and the adsorption capacity of the adsorbent $q_{e}\left(\mathrm{~g} \mathrm{mg}^{-1}\right)$. The parameters $V_{\text {eff }}$ $q_{\text {total }}$, and $q_{e}$ were estimated using Eqs. (8), (9) and (10), respectively. While $t_{\text {break }}$ and $t_{\text {sat }}$ were established when $C / C_{i}$ is equal to 0.05 and 0.9 , respectively.

$$
\begin{aligned}
& V_{\text {eff }}=Q t_{\text {sat }} \\
& q_{\text {total }}=\frac{Q}{1000} \int_{t=0}^{t=t_{\text {sat }}} C_{R} d t \\
& q_{e}=\frac{q_{\text {total }}}{m}
\end{aligned}
$$

Where, $C_{R}$ is concentration of ACT adsorbed $\left(C_{i}-C\right)\left(\mathrm{mg} \mathrm{L}^{-1}\right)$ and $m$ represents the mass of adsorbent used in the column (g).

\section{Model validation with experimental studies}

The simulation results were validated against four experimental studies. The experimental operating parameters for each adsorbate-adsorbent system are shown in Table 2. The studies were carried out in a glass burette with an internal diameter of $1.5 \mathrm{~cm}$, and a height of 50 $\mathrm{cm}$. The operation of the system was carried out with downward flow, and at a temperature of $18{ }^{\circ} \mathrm{C}$.
The ACT solution was prepared using ACT from Sigma-Aldrich (St Louis, MO, USA) with 1\% methanol from Sigma-Aldrich, HPLC grade. The $\mathrm{pH}$ of the solution was adjusted to 6 , using $0.1 \mathrm{~N} \mathrm{HCl}$ or $\mathrm{NaOH}$ solutions. $0.5 \mathrm{~cm}$ thick of gravel $(5 \mathrm{~mm}$ diameter) was placed at the bottom and top of the adsorbent bed as dispersion media to prevent channeling and ensure even distribution of the solution, as well as it helps sustain liquid flow, promote good hydraulic flow through the porous media, and reduce clogging issues [32]. The solution was pumped using a peristaltic pump, as illustrated in Fig. 2. The samples were collected at the exit of the column until saturation of the adsorbent was reached. ACT concentrations were determined using a Thermo SCIENTIF IC Genesys 10S UV-Visible spectrophotometer at a wavelength of $243 \mathrm{~nm}$.

Finally, the results of the experimental and simulation breakthrough curves were compared using the error functions sum of squared errors (SSE), absolute average deviation (AAD), and the coefficient of determination $\left(\mathrm{R}^{2}\right)$ (see Supporting Information Eqs. (11), (12), and (13)).

\section{Results and discussion}

The effects of $Q, H_{b}$ and $C_{i}$ on the breakthrough curves were studied using the adsorbents SB and CC. The range of the variable parameters both $\mathrm{SB}$ and $\mathrm{CC}$ are detailed
Acetominophen molecule

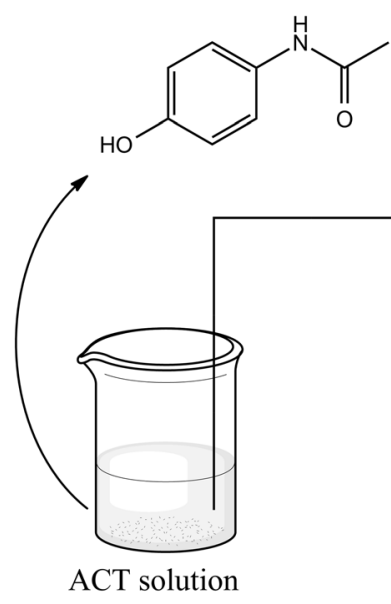

ACT solution

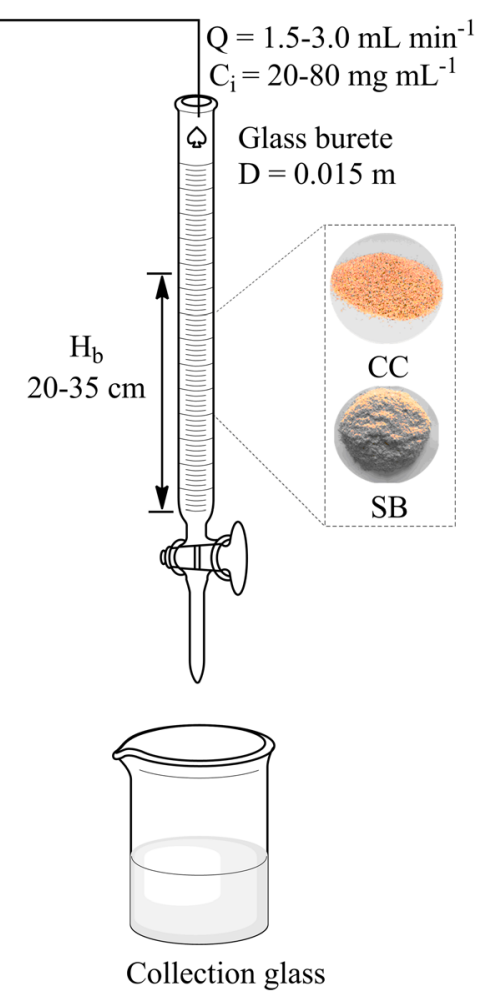

Fig. 2 Diagram of the experimental adsorption process 
in Table 2. Only one parameter was varied at a time, while the remaining two remained constant.

\section{Effect of flow rate}

Figure 3 shows the breakthrough curves when SB and $\mathrm{CC}$ are used for ACT adsorption at feed flow rates of $1.5,2.0,2.5$, and $3.0 \mathrm{~mL} \mathrm{~min}^{-1}$, a bed height of $25 \mathrm{~cm}$, and ACT initial concentration of $40 \mathrm{mg} \mathrm{L}^{-1}$.

The breakthrough times and saturation times for both adsorbents are shown in Table 3 . The results show that the breakthrough and saturation time increases as the flow rate decreases, as in practice [33]. It is well known that the flow rate determines the interstitial velocity (velocity of the solution between the pores of the adsorbent particles), and thus the time that the ACT remains in contact with the adsorbent. The higher the flow rate, the greater the interstitial velocity, and the residence time of the ACT in the column is less and less. It is evident that the less time the ACT remains inside the column, the less opportunities the ACT will have to reach the meso and micropores of the adsorbent, and deposit on them. For this reason, the amount of ACT adsorbed $q_{\text {total }}$ decreases as the flow rate increases, as seen in Table 3. In other words, if the residence time of the ACT in the bed column is not long enough, the adsorption equilibrium within the column is not reached, and the ACT solution leaves the column before this occurs, leading to shorter saturation times and lower $q_{e}$ values, for $\mathrm{SB}$ and $\mathrm{CC}$ [34]. Similar behavior is observed in other simulations performed for other pollutants [23]. A favorable advantage of working at high flow rates is that the volume of the treated effluent increases considerably, the increase from 1.5 to $3.0 \mathrm{~mL} \mathrm{~min}{ }^{-1}$ means that it is possible to treat $12 \mathrm{~mL}$ more for $\mathrm{SB}$, and $30 \mathrm{~mL}$ more for $\mathrm{CC}$, without drastically affecting the value of $q_{e}$. This fact can be beneficial when the process is carried out on an industrial scale.

On the other hand, it is observed that in all cases, $t_{\text {sat }}$ and $q_{e}$ are much greater when CC is used than SB, this could indicate that ACT has a higher affinity for $\mathrm{CC}$ than for SB. This fact can be attributed to different factors, such as physical and chemicals properties of $\mathrm{SB}$ and $\mathrm{CC}$, electrostatic and non-electrostatic interactions between adsorbate-adsorbent. In terms of physical properties, the bulk density of $\mathrm{CC}$ is higher than $\mathrm{SB}$, this means that for the same bed height, a greater quantity of $\mathrm{CC}$ is required than of SB (Table 2), which implies that $\mathrm{CC}$ will have a greater number of active sites available to be occupied by ACT. Also, the specific pore volume and the specific surface area of $\mathrm{CC}$ are greater than those in $\mathrm{SB}$, these factors could explain the fact that $V_{\text {eff }} q_{\text {total }}$, and $q_{e}$ are greater when $\mathrm{CC}$ is used (Table 3 ). The greater specific surface area of $\mathrm{CC}$ is due to its smaller pore size and its higher particle porosity compared to $\mathrm{SB}$. This can be seen in the irregular and porous morphology of CC, while SB has a laminar surface that does not favor the ACT adsorption (Fig. 1).

Regarding the chemical properties, the functional groups present on the surface of $\mathrm{SB}$ and $\mathrm{CC}$ prevail. $\mathrm{SB}$ have functional groups hydroxyl $(-\mathrm{OH})$, alkyl $\left(-\mathrm{CH}_{3}\right.$, $\left.-\mathrm{CH}_{2}\right)$, carbonyl $(-\mathrm{COOH})$, and aromatic rings, all related to the presence of cellulose, hemicellulose and

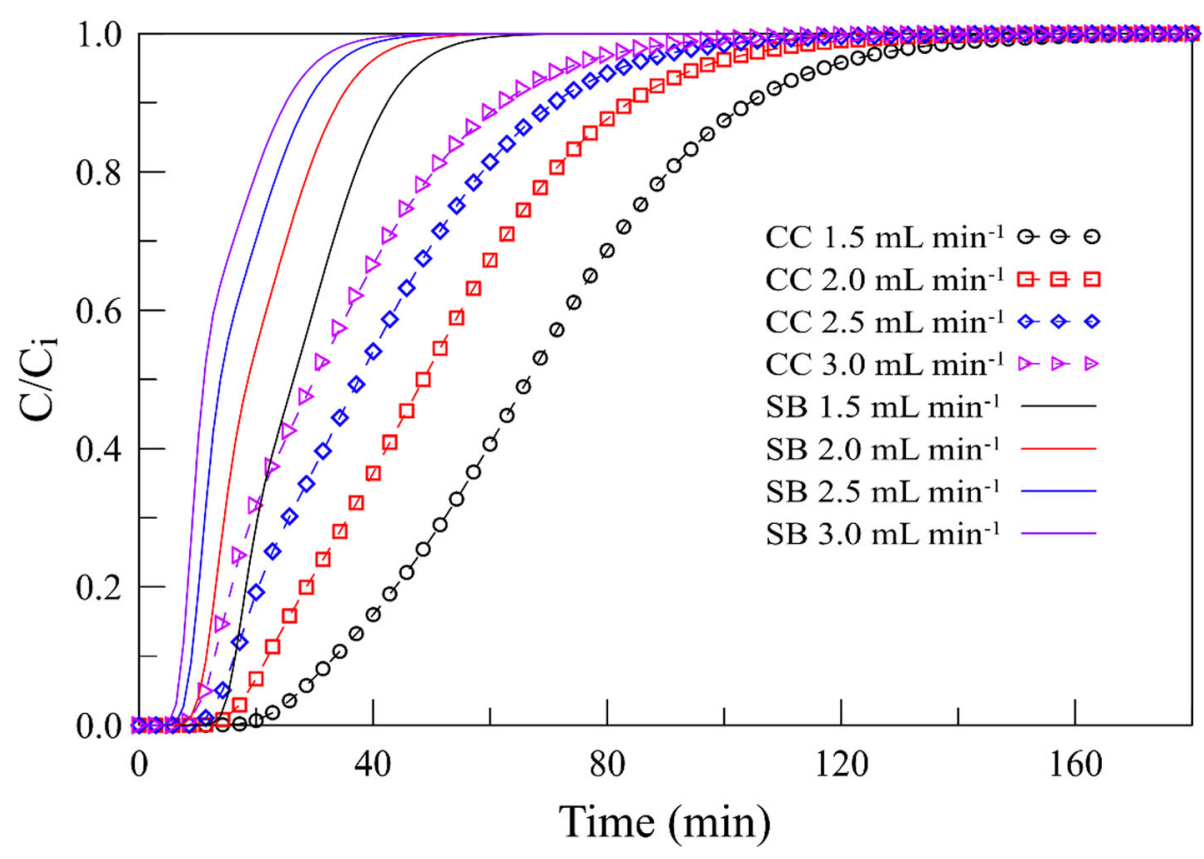

Fig. 3 Breakthrough curves of ACT adsorption on SB and CC by varying the feed flow rate 
Table 3 Column parameters obtained at various flow rates, inlet concentrations, and bed heights

\begin{tabular}{|c|c|c|c|c|c|c|c|c|c|c|c|c|}
\hline \multirow[t]{2}{*}{$\overline{\mathrm{Q}^{\mathrm{a}}}$} & \multirow[t]{2}{*}{$\mathrm{H}_{\mathrm{b}}{ }^{\mathrm{b}}$} & \multirow[t]{2}{*}{$C_{i}^{d}$} & \multicolumn{2}{|c|}{$t_{\text {break }}(\min )$} & \multicolumn{2}{|c|}{$t_{\text {sat }}(\min )$} & \multicolumn{2}{|c|}{$V_{\text {eff }}(m L)$} & \multicolumn{2}{|c|}{$q_{\text {total }}(\mathrm{mg})$} & \multicolumn{2}{|c|}{$q_{e}\left(\mathrm{mg} \mathrm{g}^{-1}\right)$} \\
\hline & & & $\overline{\mathrm{SB}}$ & $\mathrm{CC}$ & $\overline{S B}$ & CC & $\overline{S B}$ & CC & $\overline{S B}$ & CC & $\overline{\mathrm{SB}}$ & CC \\
\hline 1.5 & 25 & 40 & 15.3 & 27.6 & 43.0 & 105.7 & 64.5 & 158.6 & 1.66 & 4.20 & 0.25 & 0.29 \\
\hline 2.0 & 25 & 40 & 10.4 & 18.7 & 34.1 & 85.7 & 68.3 & 171.4 & 1.63 & 4.16 & 0.24 & 0.28 \\
\hline 2.5 & 25 & 40 & 8.1 & 14.2 & 29.1 & 71.4 & 72.7 & 178.6 & 1.62 & 4.11 & 0.24 & 0.27 \\
\hline 3.0 & 25 & 40 & 6.6 & 11.4 & 25.3 & 62.9 & 75.8 & 188.6 & 1.62 & 4.09 & 0.24 & 0.28 \\
\hline 1.5 & 20 & 40 & 11.1 & 20.4 & 35.4 & 88.6 & 53.1 & 132.8 & 1.32 & 3.35 & 0.25 & 0.28 \\
\hline 1.5 & 30 & 40 & 18.3 & 35.9 & 49.3 & 120.0 & 73.9 & 180.0 & 2.00 & 5.06 & 0.25 & 0.29 \\
\hline 1.5 & 35 & 40 & 21.6 & 45.3 & 55.6 & 137.1 & 83.5 & 205.7 & 2.33 & 5.90 & 0.25 & 0.29 \\
\hline 1.5 & 25 & 20 & 15.5 & 28.2 & 54.4 & 131.4 & 81.6 & 197.2 & 1.00 & 2.59 & 0.15 & 0.18 \\
\hline 1.5 & 25 & 60 & 14.2 & 27.3 & 37.9 & 91.4 & 56.9 & 137.1 & 2.28 & 5.53 & 0.34 & 0.36 \\
\hline 1.5 & 25 & 80 & 14.2 & 27.1 & 34.1 & 82.9 & 51.2 & 124.3 & 2.87 & 7.00 & 0.43 & 0.47 \\
\hline
\end{tabular}

$\mathrm{Q}^{\mathbf{a}}=$ flow rate $\left(\mathrm{mL} \mathrm{min} \mathrm{m}^{-1}\right)$

$\mathrm{H}_{\mathrm{b}} \mathbf{b}^{\mathbf{b}}=$ bed height $(\mathrm{cm})$

$\mathrm{C}_{\mathrm{i}}^{\mathbf{d}}=\mathrm{ACT}$ initial concentration $\left(\mathrm{mg} \mathrm{L}^{-1}\right)$

lignin $[25,26]$. Although the functional groups of CC are the same as SB, since both are lignocellulosic materials, the proportion in which they are found could change, due to the percentage content of cellulose, hemicellulose and lignin changes. This factor could also be responsible for the better adsorption capacity that $\mathrm{CC}$ has over ACT, however, to verify such an event, deep studies with tools such as Fourier transform infrared spectroscopy are necessary, therefore this analysis is outside the scope of this study.

Electrostatic interactions depend on the charge density of ACT, as well as SB and CC. The point of zero charge $\left(\mathrm{pH}_{\mathrm{PZC}}\right)$ can express the net surface charge of the adsorbent. The adsorbent surface will tend to charge positively when $\mathrm{pH}<\mathrm{pH}_{\mathrm{PZC}}$, but if $\mathrm{pH}>\mathrm{pH}_{\mathrm{PZC}}$, the adsorbent surface will be negatively charged [35]. The $\mathrm{pH}_{\mathrm{PZC}}$ is 5.2 for $\mathrm{SB}$ and 6.3 for CC. This means that if all ACT solutions are in $\mathrm{pH} 6$, SB has an overall negative charge on its surface, and the CC surface is positively charged. Similarly, adsorbate can proton in aqueous solution, one way to know if a compound can dissociate is through the $\mathrm{pK}_{\mathrm{a}}$. In the case of $\mathrm{ACT}$, its $\mathrm{pK}_{\mathrm{a}}$ is 9.38, at this $\mathrm{pH}$, half of the ACT molecules are in the protonated form and half are in the deprotonated form, see Fig. 4 [36]. But if $\mathrm{pH}<\mathrm{pK}_{\mathrm{a}}$ (in the range of $0-9.38$ ) protonated or neutral form will predominate, while the deprotonated form will be mostly present when $\mathrm{pH}>9.38$. Thus, the protonated ACT will be present in all solutions of this study, and also the surface of the adsorbents is positively charged (CC) and negatively charged (SB), which means that within the process there are not electrostatic interactions of attraction or repulsion between ACT and both adsorbents. This fact about protonated ACT was also observed on the surface of activated carbon with positive charge [36, 37]. Thus, non-electrostatic interactions such as dispersive interactions by $\pi$ electrons, and hydrogen bond formation may be involved.

Likewise, Bernal et al. [36] argue that adsorbents with high concentration of basic groups exhibit highest adsorption capacities due to $\pi$ interactions, however SB and $\mathrm{CC}$ have more acid groups than basic groups (Table 1 ). This fact could be the cause of the low adsorption capacity of SB and CC compared to other commercial adsorbents [33].<smiles>CC(=O)Nc1ccc(O)cc1</smiles>

Protonated form<smiles>CC(=O)Nc1ccc([O-])cc1</smiles>

Deprotonated form

Fig. 4 Protonated and deprotonated form of ACT molecule 


\section{Effect of bed height}

The influence of the bed height of SB and CC on ACT adsorption was studied through the breakthrough curves at bed heights of $20,25,30$, and $35 \mathrm{~cm}$ while the flow rate and ACT initial concentration remain constant at $1.5 \mathrm{~mL} \mathrm{~min}^{-1}$ and $40 \mathrm{mg} \mathrm{L}^{-1}$, respectively.

As shown in Fig. 5, when the fixed bed is SB, an increase in the bed height significantly prolongs the breakthrough and saturation time of the column, for example for $\mathrm{SB}$, the saturation time is $35.4 \mathrm{~min}$ for a bed height of $20 \mathrm{~cm}$, but it is $55.6 \mathrm{~min}$ when the bed height is $35 \mathrm{~cm}$ (Table 3). Increase in bed height makes a greater amount of adsorbent material available for the ACT removal, as well as an increase in the total surface area of the adsorbent and therefore a greater number of active sites available to be occupied by the ACT molecule [38]. A similar behavior is obtained whit $\mathrm{CC}$, the saturation time increases with the height of $\mathrm{CC}$, however, the breakthrough curves obtained with CC show a better sigmoid tendency (curve with a characteristic shape of "S") than those obtained with SB. Generally the sigmoid tendency in the breakthrough curves is favorable in the removal of an adsorbate [39], this shows that ACT adsorption on CC is an ideal system. On the other hand, the slope in SB breakthrough curves are steeper than CC curves. In general, curves with a very high slope from the breakthrough time reveal that the mass transfer is not controlled by diffusion, as is the case of SB, while a decrease in the slope of the curve indicates that the transfer zone extends through a large part of the column, and this is prone to expand as the operation progresses because the diffusion mechanisms begin to control the process, as seen for CC [38]. This fact indicates that the adsorption with $\mathrm{CC}$ meets the assumptions made in the model, hence the results are very similar to reality, as will be seen later.

Column performance parameters (Table 3 ) reveal that when the bed height increases from 20 to $35 \mathrm{~cm}$, the volume of treated effluent increases from 53.1 to $83.5 \mathrm{~mL}$ for $\mathrm{SB}$, and from 133 to $206 \mathrm{~mL}$ for CC. Besides, $q_{\text {total }}$ increases with the bed height to both adsorbents, due to the greater number of active sites available for adsorption, but at all bed heights $q_{\text {total }}$ is always greater with CC than with $\mathrm{SB}$. This happens because the mass of $\mathrm{CC}$ is greater than SB for the same bed height (Table 2). However, despite this, the amount of ACT adsorbed for each gram of adsorbent $\left(q_{e}\right)$ is slightly higher with CC at all bed heights, this shows that ACT has a slight affinity oriented more towards CC than SB. Similarly, as happened when the flow rate is varied, the breakdown and saturation times of the column are higher when using CC than SB.

\section{Effect of ACT initial concentration}

The influence of the ACT initial concentration was studied by varying $C_{i}$ while maintaining the flow rate and bed height constant at $1.5 \mathrm{~mL} \mathrm{~min}-1$ and $25 \mathrm{~cm}$, respectively. The results obtained are shown in Fig. 6 and Table 3.

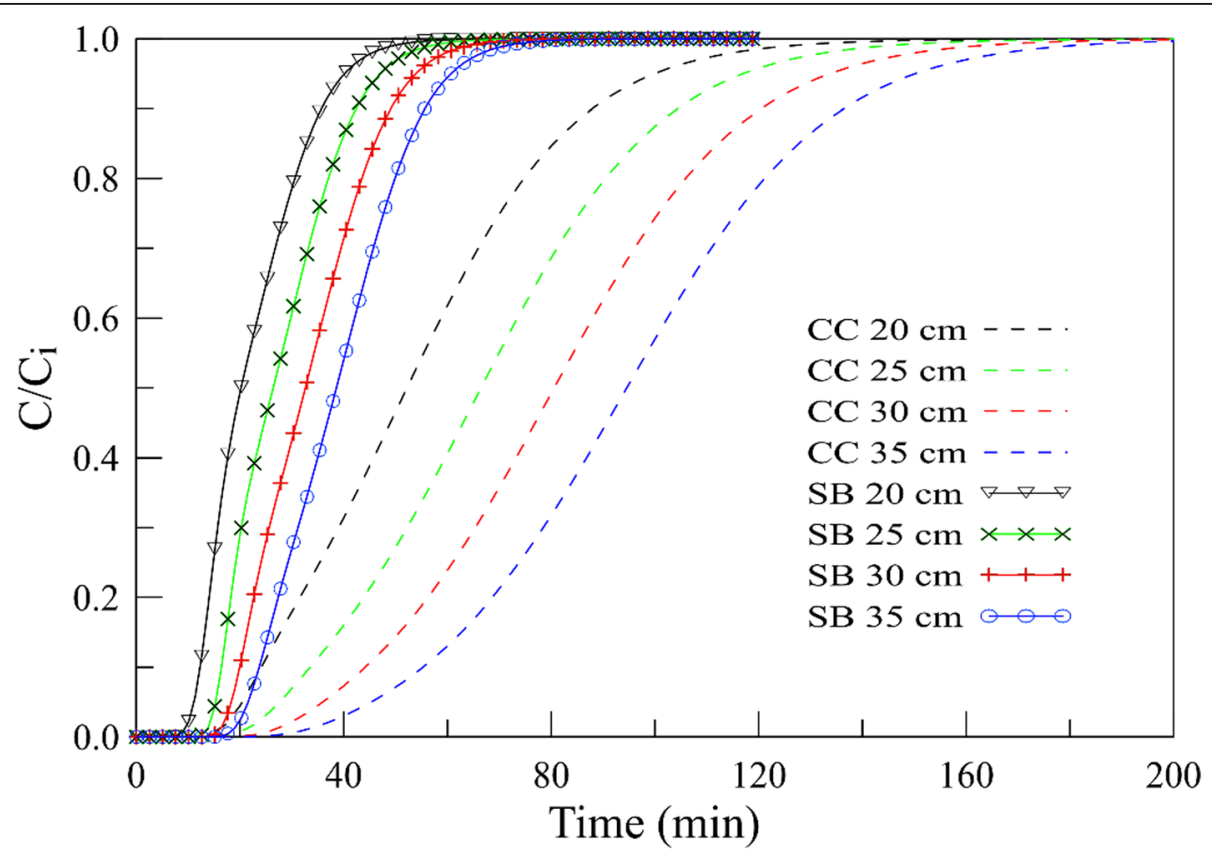

Fig. 5 Breakthrough curves of ACT adsorption on SB and CC by varying the bed height 
Breakthrough curves obtained reveal a singular behavior, since the increase in the ACT initial concentration leads to a shorter saturation time (Table 3), but the breakthrough time remains almost constant, this significantly affects the slope of the breakthrough curve. The slope of the curve decreases as the initial concentration decreases, that implies that the diffusion mechanism plays an important role, because the concentration gradient (driving force of mass transfer) between the solution and the adsorbent increases, resulting in faster transport [40]. In addition, a steeper slope indicates that the mass transfer zone decreases, and increases the degree to which adsorbent bed capacity is used. Due to this fact, the values of $q_{t o-}$ tal and $q_{e}$ increase when ACT initial concentration increases, with a maximum $q_{e}$ value at the concentration of $80 \mathrm{mg} \mathrm{L}^{-1}$ for both adsorbents, that is, the adsorbent bed is used more efficiently at high initial concentrations. Similar effect was found in the removal of ACT using granular activated carbon treated with ozone [33].

As seen in Table 3, regardless of column operating conditions, all parameters $\left(t_{\text {break }}, t_{\text {sat }} V_{\text {eff }} q_{\text {max }}\right.$ and $\left.q_{e}\right)$ are greater when $\mathrm{CC}$ is used. This demonstrate that $\mathrm{CC}$ is better than SB for ACT removal. In terms of optimal operating conditions, the maximum breakthrough and saturation time were achieved at $1.5 \mathrm{~mL} \mathrm{~min}^{-1}$ of flow rate, $35 \mathrm{~cm}$ of bed height, and $40 \mathrm{mg} \mathrm{L}^{-1}$ of initial concentration for both adsorbents.

\section{Model validation with experimental studies}

To validate the accuracy of the proposed model, experimental data were compared with 7 data obtained in the simulation. Figure 7 shows the experimental and predicted breakthrough curves for four studies.

It can be seen that the model predicts the breakthrough curves with great precision in all studies. For both adsorbents, the experimental and predicted breakthrough curves converge in almost the entire trajectory with slight variations in the initial region, the difference being more pronounced when SB is used. Hence, the breakthrough and saturation times do not differ by more than \pm 10 min for CC and SB (Table 4). The $R^{2}$ was greater than 0.99 for all studies with $\mathrm{CC}$, and less than 0.985 for SB. In addition, SSE values less than $5 \%$ were obtained, also the AAD between the experimental and simulation data was less than 0.2 for SB and CC. The model proposed by Aspen Adsorption ${ }^{\circ}$ is more acceptable for CC, due to the lower value of SSE and higher value of $R^{2}$. This is because the pore size of CC is only slightly greater than the diameter of the ACT molecule, which implies that Knudsen diffusion plays a more significant role in adsorption with $\mathrm{CC}$, whereas in $\mathrm{SB}$, pore and surface diffusion could be significant. Also, diffusion mechanisms are more relevant with the adsorption with $\mathrm{CC}$, and this meets the assumptions made in the model. Hence, the proposed model has a better fit to the experimental results for CC than for SB. In any case, the fit between the model and the experimental results for both adsorbents is encouraging, and supports the accuracy of the assumptions, equations, and calculated model parameters.

Regarding the experimental breakthrough curves, the slope of the SB curve is much steeper than the CC curve,

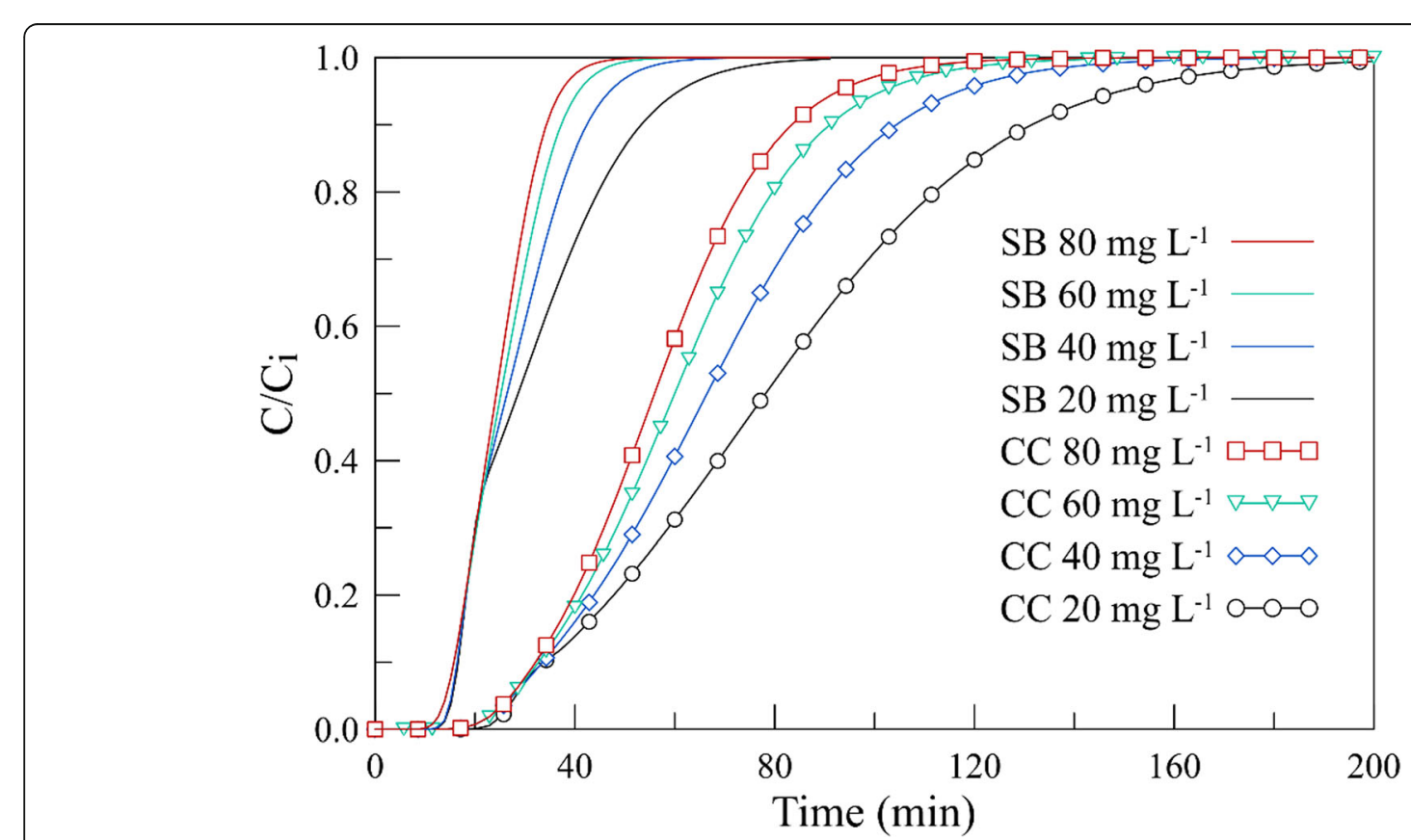

Fig. 6 Breakthrough curves of ACT adsorption on SB and CC by varying the initial concentration 

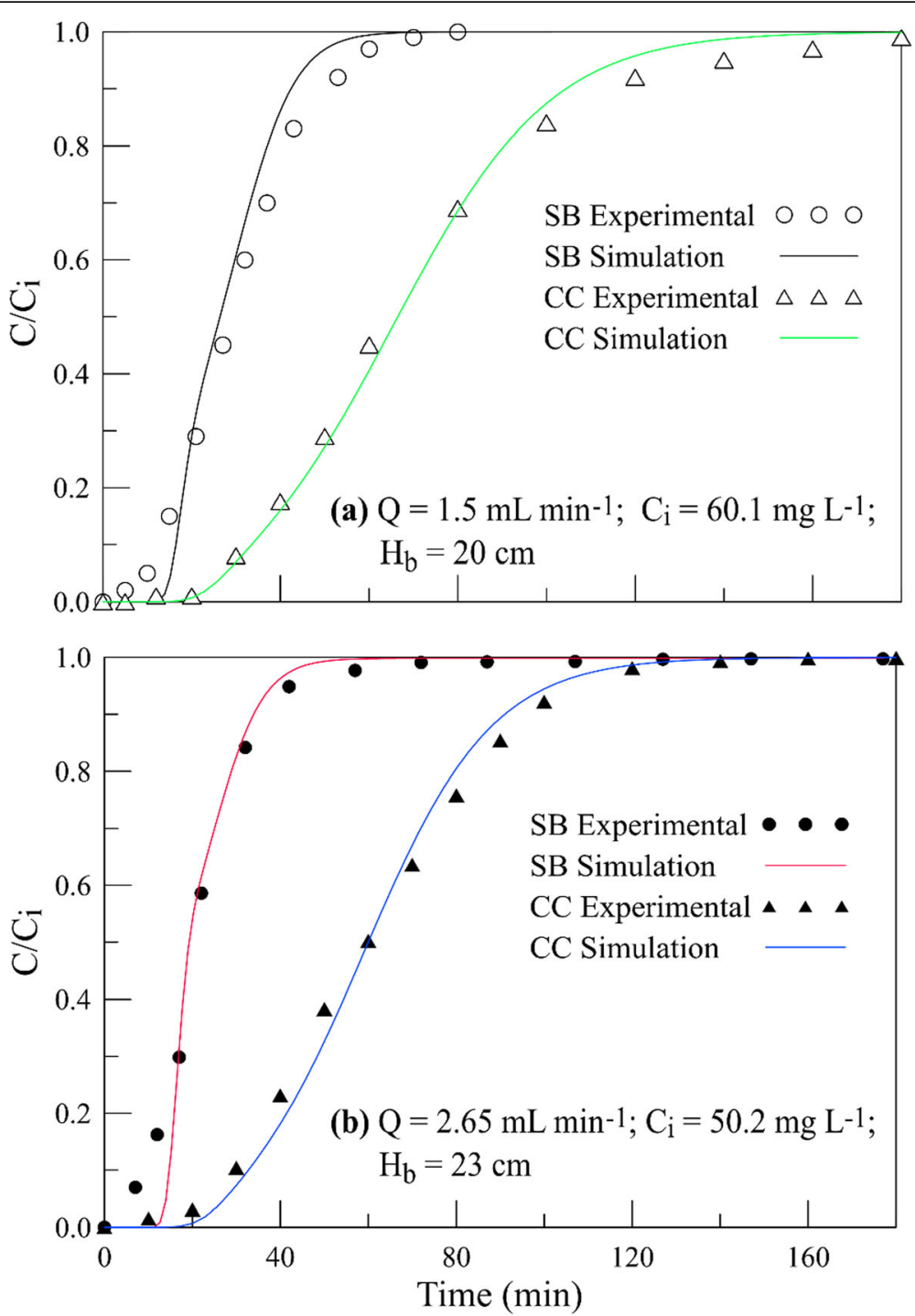

Fig. 7 Experimental and predicted breakthrough curves for ACT adsorption on SB and CC

Table 4 Column parameters and error functions for experimental and simulated results

\begin{tabular}{|c|c|c|c|c|c|c|c|c|}
\hline Operation parameters & System & Study & $t_{\text {break }}(\min )$ & $t_{\text {sat }}(\min )$ & $\begin{array}{l}\mathrm{q}_{\mathrm{e}} \\
\left(\mathrm{mg} \mathrm{g}^{-1}\right)\end{array}$ & SSE (\%) & AAD & $\mathrm{R}^{2}$ \\
\hline \multirow{4}{*}{$\begin{array}{l}\mathrm{Q}=1.5 \mathrm{~mL} \mathrm{~min}^{-1} \\
\mathrm{H}=20 \mathrm{~cm} \\
\mathrm{C}_{\mathrm{i}}=60.1 \mathrm{mg} \mathrm{L}^{-1}\end{array}$} & \multirow[t]{2}{*}{ ACT-SB } & Exp & 10.00 & 50.78 & 0.368 & \multirow[t]{2}{*}{0.041} & \multirow[t]{2}{*}{0.163} & \multirow[t]{2}{*}{0.976} \\
\hline & & Sim & 15.30 & 42.12 & 0.341 & & & \\
\hline & \multirow[t]{2}{*}{ ACT-CC } & Exp & 25.71 & 115.00 & 0.377 & \multirow[t]{2}{*}{0.010} & \multirow[t]{2}{*}{0.121} & \multirow[t]{2}{*}{0.996} \\
\hline & & Sim & 27.58 & 104.39 & 0.372 & & & \\
\hline \multirow{4}{*}{$\begin{aligned} \mathrm{Q} & =2.65 \mathrm{~mL} \mathrm{~min}^{-1} \\
\mathrm{H} & =23 \mathrm{~cm} \\
\mathrm{C}_{\mathrm{i}} & =50.2 \mathrm{mg} \mathrm{L}^{-1}\end{aligned}$} & \multirow[t]{2}{*}{$\mathrm{ACT}-\mathrm{SB}$} & Exp & 5.04 & 37.45 & 0.380 & \multirow[t]{2}{*}{0.032} & \multirow[t]{2}{*}{0.155} & \multirow[t]{2}{*}{0.984} \\
\hline & & Sim & 13.97 & 33.91 & 0.361 & & & \\
\hline & \multirow[t]{2}{*}{ ACT-CC } & Exp & 22.60 & 96.76 & 0.421 & \multirow[t]{2}{*}{0.012} & \multirow[t]{2}{*}{0.175} & \multirow[t]{2}{*}{0.994} \\
\hline & & Sim & 27.31 & 91.03 & 0.429 & & & \\
\hline
\end{tabular}


this corroborates that $\mathrm{ACT}$ adsorption on $\mathrm{CC}$ has a faster transfer zone, as observed in all simulations. The most notable of these results is that according to the Aspen Adsorption $^{\circ}$ model, the adsorption capacity of ACT is higher when $\mathrm{CC}$ is used compared with $\mathrm{SB}$, and this is confirmed with the experimental results, where $\mathrm{CC}$ has an adsorption capacity greater than SB in all experimental studies. Furthermore, the adsorption capacity values obtained from the predicted curves practically coincide with those obtained from experimentation. This implies that the simulator could be used to help establish which adsorbent has a higher adsorption capacity for ACT removal, and thus rule out those of lower efficacy. This in practice could save a considerable amount of time, and above all economic resources. Likewise, it would speed up the search for effective materials for ACT removal from wastewaters. Certainly, much more research is needed to define whether this is effective for other adsorbate-adsorbent systems, since the adsorption capacity depends on many factors that are outside the scope of the Aspen Adsorption simulator.

\section{Conclusions}

A model made up of the mass balance, linear lumped resistance model, and Langmuir isotherm was proposed in Aspen Adsorption to determine the breakthrough curves of ACT adsorption on sugarcane bagasse and corn cob, and then compare adsorption capacity of both adsorbents. Based on the results obtained, ACT has a slightly higher affinity for the corn cob than for sugarcane bagasse. With corn cob, saturation times and adsorption capacity obtained are greater than sugarcane bagasse in all simulations carried out. Breakthrough and saturation times are longer when the column operates at low flow rates, large bed heights, and low ACT initial concentrations for both adsorbents. The maximum breakthrough and saturation time were achieved at $1.5 \mathrm{~mL} \mathrm{~min}^{-1}$ of flow rate, $35 \mathrm{~cm}$ of bed height, and $40 \mathrm{mg} \mathrm{L}^{-1}$ of initial concentration for both sugarcane bagasse and corn cob, while the highest adsorption capacity was achieved at $1.5 \mathrm{~mL} \mathrm{~min}^{-1}$ of flow rate, $25 \mathrm{~cm}$ of bed height, and $80 \mathrm{mg} \mathrm{L}^{-1}$ of initial concentration for both adsorbents. Experimental studies supported the accuracy of the proposed model, stating that diffusion mechanisms and especially Knudsen diffusion are predominant in the ACT adsorption with corn cob, while surface and pore diffusions could be more relevant in the system ACT- sugarcane bagasse. In addition, experimentation established that the model predicted not only the ACT outlet composition, but also the adsorption capacity of sugarcane bagasse and corn cob, establishing that ACT adsorbs better on corn cob. Aspen Adsorption ${ }^{\circ}$ could be used to extend the validity of the model with a number of pharmaceutical compounds tested with different adsorbents.

\section{Nomenclature}

\section{Notation}

Cfinal concentration $\left(\mathrm{mg} \mathrm{L}^{-1}\right)$.

$C_{i}$ initial concentration $\left(\mathrm{mg} \mathrm{L}^{-1}\right)$.

$C_{R}$ concentration of ACT adsorbed $\left(\mathrm{mg} \mathrm{L}^{-1}\right)$.

$d_{p}$ diameter of the adsorbent particle $(\mathrm{m})$.

Dcolumn diameter $(\mathrm{m})$.

$D_{k}$ Knudsen diffusion coefficient $\left(\mathrm{m}^{2} \mathrm{~s}^{-1}\right)$.

$D_{m}$ molecular diffusion coefficient $\left(\mathrm{m}^{2} \mathrm{~s}^{-1}\right)$.

$D_{p}$ effective pore diffusivity coefficient $\left(\mathrm{m}^{2} \mathrm{~s}^{-1}\right)$.

$D_{Z}$ axial dispersion coefficient $\left(\mathrm{m}^{2} \mathrm{~s}^{-1}\right)$.

$H_{b}$ bed height $(\mathrm{m})$.

$I P_{1}$ maximum adsorption capacity in the adsorbent $(\mathrm{kmol}$ $\mathrm{kg}^{-1}$ ).

$I P_{2}$ energy constant for component i $\left(\mathrm{m}^{3} \mathrm{kmol}^{-1}\right)$.

$m$ mass of adsorbent $(\mathrm{g})$.

$M_{s}$ molecular weight of the solution $\left(\mathrm{kg} \mathrm{kmol}^{-1}\right)$.

$K_{i}$ global mass transfer coefficient $\left(\mathrm{s}^{-1}\right)$.

$k_{f i}$ external film mass transfer coefficient $\left(\mathrm{m} \mathrm{s}^{-1}\right)$.

$k_{L}$ energy constant related to the heat of adsorption (L $\mathrm{mg}^{-1}$ ).

Ppressure across the bed $(\mathrm{Pa})$.

$q$ concentration of adsorbate adsorbed $\left(\mathrm{mg} \mathrm{g}^{-1}\right)$.

$q_{e}$ amount of solute removed per unit mass of adsorbent or adsorption capacity $\left(\mathrm{mg} \mathrm{g}^{-1}\right)$.

$q_{\text {max }}$ maximum adsorption of the solid phase in monolayer $\left(\mathrm{mg} \mathrm{g}^{-1}\right)$.

$q_{\text {total }}$ total amount of ACT adsorbed (mg).

Qflow rate of the solution $\left(\mathrm{mL} \mathrm{min}^{-1}\right)$.

$R_{p}$ particle radius (m).

$V_{\text {eff }}$ total treated volume (mL).

$v_{i}$ interstitial velocity of the solution $\left(\mathrm{m} \mathrm{s}^{-1}\right)$.

$v_{s}$ superficial velocity of the solution $\left(\mathrm{m} \mathrm{s}^{-1}\right)$.

$w_{i}$ load of contaminant removed $\left(\mathrm{kmol} \mathrm{kg}^{-1}\right)$.

$z$ distance along the bed (m).

\section{Greek Letters}

$\rho_{a}$ bulk density of the adsorbent $\left(\mathrm{kg} \mathrm{m}^{-3}\right)$.

$\rho_{p}$ density of the adsorbent particle $\left(\mathrm{kg} \mathrm{m}^{-3}\right)$.

$\mu$ dynamic viscosity of the solution $\left(\mathrm{kg} \mathrm{m}^{-1} \mathrm{~s}^{-1}\right)$.

$\psi$ form factor of the adsorbent particle.

$\varepsilon_{b}$ bed void fraction.

$\varepsilon_{p}$ particle porosity.

\section{Supplementary information}

Supplementary information accompanies this paper at https://doi.org/10. 1186/s42834-020-00063-7.

\section{Additional file 1.}

\section{Acknowledgments}

The author thanks the Centro de Estudios Ambientales (CEA) of the Universidad de Cuenca that has offered the possibility of carrying out this study. 


\section{Author's contributions}

DMJ proposed the model in Aspen Adsorption ${ }^{\circledR}$ and ran the simulations. He carried out the lab experimental studies, and finally he wrote and edited the final manuscript. The author read and approved the final manuscript.

\section{Funding}

The present study had no funding sources of any kind.

\section{Availability of data and materials}

All data generated or analyzed during this study are included in this article and in the Supporting Information.

\section{Competing interests}

The author declares that there is no conflict of interest regarding the publication of this study.

Received: 13 April 2020 Accepted: 2 September 2020

\section{Published online: 01 October 2020}

\section{References}

1. Shraim A, Diab A, Alsuhaimi A, Niazy E, Metwally M, Amad M, et al. Analysis of some pharmaceuticals in municipal wastewater of Almadinah Almunawarah. Arab J Chem 2017:10:S719-29.

2. Patel M, Kumar R, Kishor K, Mlsna T, Pittman CU, Mohan D. Pharmaceuticals of emerging concern in aquatic systems: chemistry, occurrence, effects, and removal methods. Chem Rev 2019;119:3510-673.

3. Kumar R, Tscharke B, O'Brien J, Mueller JF, Wilkins C, Padhye LP. Assessment of drugs of abuse in a wastewater treatment plant with parallel secondary wastewater treatment train. Sci Total Environ 2019;658:947-57.

4. Bexfield LM, Toccalino PL, Belitz K, Foreman WT, Furlong ET. Hormones and pharmaceuticals in groundwater used as a source of drinking water across the United States. Environ Sci Technol 2019:53:2950-60.

5. Pinos Velez VP, Esquivel-Hernandez G, Cipriani-Avila I, Mora-Abril E, Cisneros JF, Alvarado A, et al. Emerging contaminants in trans-American waters. Rev Ambient Água 2019;14:e2436.

6. Escalante MCK, Abdennour A, Farah A, Rivera-Richardson E, Burgos F, Forero I, et al. Prescription patterns of analgesics, antipyretics, and non steroidal anti-inflammatory drugs for the management of fever and pain in pediatric patients: a cross-sectional, multicenter study in Latin America, Africa, and the Middle East. Pragmat Obs Res 2019;10:41-51.

7. Kostich MS, Batt AL, Lazorchak JM. Concentrations of prioritized pharmaceuticals in effluents from 50 large wastewater treatment plants in the US and implications for risk estimation. Environ Pollut 2014:184:354-9.

8. Kasprzyk-Hordern B, Dinsdale RM, Guwy AJ. The removal of pharmaceuticals, personal care products, endocrine disruptors and illicit drugs during wastewater treatment and its impact on the quality of receiving waters. Water Res 2009:43:363-80.

9. Lin AY, Tsai YT. Occurrence of pharmaceuticals in Taiwan's surface waters: impact of waste streams from hospitals and pharmaceutical production facilities. Sci Total Environ 2009;407:3793-802.

10. K'oreje KO, Demeestere K, De Wispelaere P, Vergeynst L, Dewulf J, Van Langenhove $\mathrm{H}$. From multi-residue screening to target analysis of pharmaceuticals in water: development of a new approach based on magnetic sector mass spectrometry and application in the Nairobi River basin, Kenya. Sci Total Environ 2012;437:153-64.

11. Fram MS, Belitz K. Occurrence and concentrations of pharmaceutical compounds in groundwater used for public drinking-water supply in California. Sci Total Environ 2011:409:3409-17.

12. Minguez L, Pedelucq J, Farcy E, Ballandonne C, Budzinski H, Halm-Lemeille MP. Toxicities of 48 pharmaceuticals and their freshwater and marine environmental assessment in northwestern France. Environ Sci Pollut $R$ 2016;23:4992-5001.

13. Singh S, Kumar V, Datta S, Dhanjal DS, Sharma K, Samuel J, et al. Current advancement and future prospect of biosorbents for bioremediation. Sci Total Environ 2020;709:135895.

14. Zhou $Y$, Zhang $L$, Cheng Z. Removal of organic pollutants from aqueous solution using agricultural wastes: a review. J Mol Liq 2015;212:739-62.

15. Weng CH, Lin YT, Tzeng TW. Removal of methylene blue from aqueous solution by adsorption onto pineapple leaf powder. J Hazard Mater 2009; 170:417-24.
16. Weng CH, Lin YT, Chen YJ, Sharma YC. Spent green tea leaves for decolourisation of raw textile industry wastewater. Color Technol 2013;129: 298-304.

17. Penafiel ME, Vanegas E, Bermejo D, Matesanz JM, Ormad MP. Organic residues as adsorbent for the removal of ciprofloxacin from aqueous solution. Hyperfine Interact 2019;240:71.

18. Kanawade SM, Gaikwad RW. Removal of dyes from dye effluent by using sugarcane bagasse ash as an adsorbent. Int J Chem Eng Appl 2011;2:203-6.

19. Vera L, Uguna MF, Garcia N, Flores M, Vazquez V, Aloma I. Desarrollo de materiales sorbentes para la eliminación de metales pesados de las aguas residuales mineras [Development of sorbent materials for removing heavy metals from mining wastewater]. Afinidad. 2016;73:135-9 [in Spanish].

20. ATI. Introduction to Aspen Adsorption. Bedford: Aspen Technology Inc.; 2010.

21. Xiao YH, Xiao HY, Li BY, Qin JL, Oiu S, He GH. Optimization of helium/ methane adsorption separation process based on Aspen Adsorption simulation. CIESC J 2019:70:2556-63.

22. Plaza MG, Duran I, Querejeta N, Rubiera F, Pevida C. Experimental and simulation study of adsorption in postcombustion conditions using a microporous biochar. 1. $\mathrm{CO}_{2}$ and $\mathrm{N}_{2}$ adsorption. Ind Eng Chem Res 2016;55: 3097-112.

23. Soriano AN, Orfiana ON, Pangon MBJ, Nieva AD, Adornado AP. Simulated biosorption of $\mathrm{Cd}(\mathrm{II})$ and $\mathrm{Cu}(\mathrm{II})$ in single and binary metal systems by water hyacinth (Eichhornia crassipes) using Aspen Adsorption ${ }^{\circledR}$. ASEAN J Chem Eng 2016;16:21-43.

24. Ahmed S, Unar IN, Khan HA, Maitlo G, Mahar RB, Jatoi AS, et al. Experimental study and dynamic simulation of melanoidin adsorption from distillery effluent. Environ Sci Pollut R 2020;27:9619-36.

25. Coronel Iniguez VF. Biosorción de ciprofloxacina con bagazo de caña y mazorca de maíz en tanque agitado [Ph.D. Dissertation]. Cuenca: University of Cuenca; 2017 [in Spanish].

26. Freire Moncayo PS. Remoción de paracetamol por biosorción en tanque agitado usando cáscara de cacao y bagazo de caña de azúcar [Ph.D. Dissertation]. Cuenca: University of Cuenca; 2018 [in Spanish].

27. Mestre AS, Tyszko E, Andrade MA, Galhetas M, Freire C, Carvalho AP. Sustainable activated carbons prepared from a sucrose-derived hydrochar: remarkable adsorbents for pharmaceutical compounds. RSC Adv 2015;5:19696-707.

28. Bouillot B, Teychene S, Biscans B. An evaluation of thermodynamic models for the prediction of drug and drug-like molecule solubility in organic solvents. Fluid Phase Equilibr 2011;309:36-52.

29. Tien C. Adsorption calculations and modelling. Newton: ButterworthHeinemann; 1994

30. Glueckauf E, Coates JI. Theory of chromatography. Part IV. The influence of incomplete equilibrium on the front boundary of chromatograms and on the effectiveness of separation. J Chem Soc. 1947(0):1315-21. https://doi. org/10.1039/JR9470001315

31. Saadi Z, Fazaeli R, Vafajoo L, Naser I. Adsorptive removal of apramycin antibiotic from aqueous solutions using Tween 80-and Triton X-100 modified clinoptilolite: experimental and fixed-bed modeling investigations. Int J Environ Heal R. 2020;30(5):558-83. https:/doi.org/10.1080/09603123.2019.1612039.

32. Hanif A. Evaluation of a trickle flow leach bed reactor for anaerobic digestion of high solids cattle manure [Master's Thesis]. Fort Collins: Colorado State Univ; 2013

33. Li YY, Kurniawan TA, Zhu MT, Ouyang T, Avtar R, Othman MHD, et al. Removal of acetaminophen from synthetic wastewater in a fixed-bed column adsorption using low-cost coconut shell waste pretreated with $\mathrm{NaOH}, \mathrm{HNO}_{3}$, ozone, and/or chitosan. J Environ Manage 2018;226:365-76.

34. Simate GS, Ndlovu S. The removal of heavy metals in a packed bed column using immobilized cassava peel waste biomass. J Ind Eng Chem 2015;21:635-43.

35. Menendez JA, Illan-Gomez MJ, Leon CALY, Radovic LR. On the difference between the isoelectric point and the point of zero charge of carbons. Carbon. 1995:33:1655-7.

36. Bernal V, Erto A, Giraldo L, Moreno-Pirajan JC. Effect of solution pH on the adsorption of paracetamol on chemically modified activated carbons. Molecules. 2017;22:1032

37. Ferreira RC, Couto Junior OM, Carvalho KQ, Arroyo PA, Barros MASD. Effect of solution $\mathrm{pH}$ on the removal of paracetamol by activated carbon of dende coconut mesocarp. Chem Biochem Eng Q 2015:29:47-53.

38. Zulfadhly Z, Mashitah MD, Bhatia S. Heavy metals removal in fixed-bed column by the macro fungus Pycnoporus sanguineus. Environ Pollut 2001 112:463-70. 
39. Plaza Cazon J. Remoción de metales pesados empleando algas marinas [Ph. D. Dissertation]. La Plata: National Univ of La Plata; 2012 [in Spanish].

40. El-Kamash AM. Evaluation of zeolite $\mathrm{A}$ for the sorptive removal of $\mathrm{Cs}^{+}$and $\mathrm{Sr}^{2+}$ ions from aqueous solutions using batch and fixed bed column operations. J Hazard Mater 2008;151:432-45.

\section{Publisher's Note}

Springer Nature remains neutral with regard to jurisdictional claims in published maps and institutional affiliations.

Ready to submit your research? Choose BMC and benefit from:

- fast, convenient online submission

- thorough peer review by experienced researchers in your field

- rapid publication on acceptance

- support for research data, including large and complex data types

- gold Open Access which fosters wider collaboration and increased citations

- maximum visibility for your research: over $100 \mathrm{M}$ website views per year

At $\mathrm{BMC}$, research is always in progress.

Learn more biomedcentral.com/submissions 